\title{
MODERNISASI PENDIDIKAN ISLAM: SKETSA PESANTREN
}

\author{
Zaini Dahlan \\ Fakultas Ilmu Tarbiyah dan Keguruan UIN SU Medan \\ zainidahlan@uinsu.ac.id
}

\begin{abstract}
Abstrak
Pesantren is an educational institution that has a long and unique history. Historically, pesantren were among the earliest Islamic educational institutions and still survive today. In contrast to educational institutions that emerged later, pesantren have been very instrumental in printing ulama cadres and then play an active role in the spread of Islam and the transfer of knowledge. However, in its development the pesantren has undergone a transformation that allows it to lose its identity if its traditional values are not preserved. Today the existence of pesantren has experienced such a development that the intended components are increasingly increasing and equipped with infrastructure and facilities. In its growth history, pesantren have undergone several phases of development including the existence of pesantren specifically mixing with these developments. This paper simply discusses the modernization of Islamic education in pesantren, which then reinforces it with the objectives, curriculum, human resources, learning methods, institutions, infrastructure and facilities and the resulting changes.
\end{abstract}

Kata Kunci: Modernisasi, Pendidikan Islam, Pesantren

\section{PENDAHULUAN}

Sejarah perkembangan pendidikan Islam dimulai sejak agama Islam masuk ke Indonesia, yaitu kira-kira pada abad kedua belas Masehi.(Yunus, 1984:10) Salah satu statement yang sulit di sangkal, bahwa Islam sangat besar pengaruhnya bagi pembentukan budaya dan tradisi masyarakat Indonesia sampai hari ini. Eksistensi Islam di Indonesia sangat mempengaruhi kultur masyarakat yang mayoritas beragama Islam dan terbesar di dunia. Hal ini merupakan bukti bahwa Islam sangat berpengaruh terlebih dalam pembinaan masyarakat melalui pendidikan yang sudah ada di pesisir terutama di Aceh dan Selat Malaka, dan salah satu pusat pendidikan Islam di Indonesia pada masa awal adalah pesantren.

Pesantren merupakan lembaga pendidikan yang memiliki sejarah panjang dan unik. Pesantren juga sebuah lembaga pendidikan dan penyiaran agama Islam. Secara historis, pesantren termasuk lembaga pendidikan Islam yang paling awal dan masih bertahan sampai hari ini. Berbeda dengan lembaga-lembaga pendidikan yang muncul kemudian, pesantren telah sangat berjasa dalam mencetak kader-kader ulama dan 
kemudian berperan aktif dalam penyebaran agama Islam dan transfer ilmu pengetahuan. Namun, dalam perkembangannya pesantren telah mengalami transformasi yang memungkinkannya kehilangan identitas jika nilai-nilai tradisionalnya tidak dilestarikan.(Raharjo, 1985:245)

Pondok pesantren di Indonesia memiliki peran yang sangat besar, baik bagi kemajuan Islam itu sendiri maupun bagi bangsa Indonesia secara keseluruhan. Berdasarkan catatan yang ada, kegiatan pendidikan agama di Nusantara telah dimulai sejak tahun 1596. Kegiatan agama inilah yang kemudian dikenal dengan nama pondok pesantren.(Fattah dan Abdul, 2005:11)

Elemen dasar pesantren adalah sebuah pondok yang pada dasarnya merupakan sebuah asrama pendidikan Islam tradisional, di mana para siswanya (santri) tinggal bersama di bawah bimbingan seorang atau lebih guru yang lebih dikenal dengan sebutan Kyai.(Dhofier, 1982:49) Sebutan Kyai ini bagi guru yang laki-laki, sedangkan bagi guru yang perempuan ini disebut dengan Nyai. Panggilan Kyai dan Nyai mempunyai arti orang tua. Kyai tidak saja berarti tua, tetapi juga sakral, keramat, dan sakti.

Dewasa ini keberadaan pesantren sudah mengalami perkembangan sedemikian rupa, sehingga komponen-komponen yang dimaksudkan semakin lama makin bertambah dan dilengkapi prasarana dan sarananya. Dalam sejarah pertumbuhannya, pesantren telah mengalami beberapa fase perkembangan termasuk adanya pesantren khusus percampuran dengan perkembangan tersebut, maka kemudian pesantren hari ini memiliki santri laki-laki dan perempuan.

Tulisan yang sederhana ini, akan membahas modernisasi pendidikan Islam yang ada di pesantren, yang kemudian mempertegasnya dengan tujuan, kurikulum, sumber daya manusia, metode pembelajaran, kelembagaan, prasarana dan sarana serta perubahan yang dihasilkan.

\section{PEMBAHASAN}

\section{Tujuan}

Pesantren atau pondok adalah lembaga yang mewujudkan proses wajar perkembangan pendidikan nasional, yang dalam segi historis, pesantren tidak hanya mengandung makna keislaman, tetapi juga keaslian (indigenous) Indonesia, sebab lembaga yang serupa, sudah terdapat pada masa kekuasaan Hindu-Budha, sedangkan 
Islam meneruskan dan mengislamkannya.(Madjid, 1997:3) Institusi ini merupakan salah satu bentuk akulturasi yang dilakukan beberapa ulama penyebar agama Islam di nusantara. Akulturasi inilah yang kemudian menjadikan pondok pesantren tidak terlepas dari tradisi yang dilakukan pendahulu-pendahulu mereka. Ada semacam pelestarian yang dilakukan oleh para pendiri pondok pesantren yang masih tergolong kolot untuk tidak merombak struktur dan sistem yang terdapat di dalam pesantren dengan alasan yang biasanya tidak rasional. Namun demikian, hal ini tidak berarti mengecilkan peranan Islam dalam mempelopori pendidikan di Indonesia.

Tujuan merupakan hal yang sangat penting dalam mencapai sesuatu yang dikehendaki, tanpa adanya suatu tujuan yang jelas maka roda perjalanan sebuah lembaga tidak akan berjalan dengan baik, termasuk dalam lembaga pondok pesantren. Ironisnya, pondok pesantren sebagai lembaga pendidikan tidak memiliki formulasi tujuan yang jelas, baik dalam tataran institusional, kurikuler maupun instruksional umum dan khusus. Tujuan yang dimilikinya hanya ada dalam angan-angan.(Qomar, 2002:3) Selama ini memang belum pernah ada rumusan tertulis mengenai tujuan pendidikan pesantren.(Maunah, 2009:25) Akibatnya, beberapa penulis merumuskan tujuan itu hanya berdasarkan perkiraan (asumsi) dan atau wawancara.

Adapun tujuan pondok pesantren menurut Ziemiek sebagaimana dinukil oleh Qomar adalah "membentuk kepribadian, memantapkan akhlak dan melengkapinya dengan pengetahuan". Sementara itu Arifin mengemukakan bahwa tujuan pondok pesantren ada 2 yaitu :

a. Tujuan umum

Membimbing anak didik untuk menjadi manusia yang berkepribadian Islam dengan ilmu agamanya ia sanggup menjadi muballigh Islam dalam masyarakat sekitar melalui ilmu dan amalnya.

b. Tujuan khusus

Mempersiapkan para santri untuk menjadi orang alim dalam ilmu agama yang diajarkan oleh Kyai yang bersangkutan serta mengamalkannya dalam masyarakat.(Arifi, 1991:248)

Sedangkan tujuan institusional pondok pesantren yang lebih luas dengan tetap mempertahankan hakikatnya dan diharapkan menjadi tujuan pondok pesantren secara nasional pernah diputuskan dalam Musyawarah/Lokakarya Intensifikasi Perkembangan Pondok Pesantren di Jakarta yang berlangsung pada 2 s/d 6 Mei 1978, 
yang dikutip oleh Qomar, tujuan umum pesantren adalah membina warga negara agar berkepribadian Muslim sesuai dengan ajaran-ajaran agama Islam dan menanamkan rasa keagamaan tersebut pada semua segi kehidupannya serta menjadikannya sebagai orang yang berguna bagi agama, masyarakat, dan negara.

Adapun tujuan khusus pesantren adalah sebagai berikut:

a. Mendidik siswa/santri anggota masyarakat untuk menjadi seorang muslim yang bertakwa kepada Allah swt., berakhlak mulia, memiliki kecerdasan, keterampilan dan sehat lahir batin sebagai warga Negara yang berpancasila;

b. Mendidik siswa/santri untuk menjadikan manusia muslim selaku kader-kader ulama dan muballigh yang berjiwa ikhlas, tabah, tangguh, wiraswasta dalam mengamalkan sejarah Islam secara utuh dan dinamis;

c. Memperoleh kepribadian dan mempertebal semangat kebangsaan agar dapat menumbuhkan manusia-manusia pembangunan yang dapat membangun dirinya dan bertanggungjawab kepada pembangunan bangsa dan Negara;

d. Mendidik tenaga-tenaga penyuluh pembangunan mikro (keluarga) dan regional (pedesaan/masyarakat lingkungannya);

e. Agar menjadi tenaga-tenaga yang cakap dalam berbagai sektor pembangunan, khususnya pembangunan mental spiritual;

f. Untuk membantu meningkatkan kesejahteraan sosial masyarakat lingkungan dalam rangka usaha usaha pembangunan bangsa.

Rumusan tujuan ini adalah yang paling rinci di antara rumusan yang pernah diungkapkan beberapa peneliti di atas, tetapi harapan untuk memberlakukan tujuan tersebut bagi seluruh pesantren rupanya kandas. Kyai-kyai pesantren tidak mentransfer rumusan tersebut secara tertulis sebagai tujuan bagi pesantrennya kendati orientasi pesantren tidak jauh berbeda dengan kehendak tujuan tersebut.

Dari beberapa tujuan tersebut, dapat disimpulkan bahwa modernisasi tujuan pendidikan pondok pesantren bukan hanya menciptakan dan mengembangkan kepribadian Muslim dengan ilmu-ilmu agama, yaitu meniciptakan kepribadian yang beriman dan bertaqwa kepada Tuhan Yang Maha Esa, berakhlak mulia serta dapat menguasai ajaran-ajaran Islam, akan tetapi juga mengombinasikan ilmu-ilmu agama itu dengan ilmu-ilmu umum sehingga dapat diamalkan dan bermanfaat bagi agama, masyarakat, dan negara. 


\section{Kurikulum}

Kurikulum merupakan alat yang sangat penting dalam keberhasilan suatu pendidikan.Tanpa adanya kurikulum yang baik dan tepat,anak akan sulit dalam mencapai tujuan dan sasaranpendidikan yang telah dicita-citakanoleh sebuah lembaga pendidikan,baik formal,informal,maupun non formal.Karena segala sesuatu harus ada manajemennya bila ingin menghasilkan suatu yang baik,sesuai dengan yang diharapkan.

Kurikulum yang dikembangkan di pesantren dapat dibedakan menjadi dua jenis sesuai dengan pola pesantren itu sendiri,yaitu:

1. Pesantren Salaf (tradisional); Kurikulum pesantren salaf yang statusnya sebagai lembaga pendidikan nonformal yang hanya mempelajari kitab-kitab klasik yang meliputi: Tauhid, tafsir, hadits, ushul fiqih, tasawuf, bahasa arab (nahwu dan sharf, balaghah, tajwid, mantiq dan akhlak). Kurikulum pesantren ini berdasarkan kemudahan dan kompleksitas ilmu atau masalah yang dibahas dalam kitab. Jadi ada tingkat awal, menengah dan tingkat lanjutan.

2. Pesantren Modern; Pesantren jenis ini yang mengkombinasikan antara pesantren salafi dan juga model pesantren modern (formal) dengan mendirikan suatu pendidikan semacam SD/MI, SMP/MTS, SMA/SMK/MA, bahkan sampai ke perguruan tinggi, misalnya Darul Arafah, mendirikan sekolah tinggi Darul Arafah. Kurikulum pesantren modern juga mengembangkan kurikulum pesantren salafi, modern dan kurikulum pendidikan Islam khusus, pesantren yang dialokasikan dalam bentuk muatan lokal atau mungkin diterapkan melalui kebijaksanaan sendiri. Sebut saja misalnya pesantren Darul Mursyid yang berlokasi di Desa Simanosor, Kecamatan Saipar Dolok Hole, Tapanuli Selatan. Pesantren yang dibangun tahun 1991 ini mengikuti jejak Pesantren Darussalam Gontor Ponorogo. Pesantren ini memberlakukan sistem belajar aktif dan disiplin dan mengharuskan bagi santrinya dua bahasa, yakni bahasa Arab dan bahasa Inggris sebagi bahasa sehari-hari, baik saat belajar dan berkomunikasi antara sesama santri. Sebab dengan dua bahasa ini para santri akan bisa mengikuti perkembangan informasi dan teknologi global, sesuai dengan citacita pendiri pesantre ini (Alm. Drs. H. Ihutani Ritonga), yakni "Melahirkan santri modern dengan pengetahuan global”. 
Di antara kurikulum khusus, pesantren Darul Mursyid adalah bagi suatu yang gemar berwirausaha/berwiraswasta seperti perbengkelan dan peternakan ikan, persatuan menyediakan fasilitasnya. Karena itu pesantren yang seluas 15 Hektare (Ha) ini telah tersedia balai latihan bengkel, kolam ikan dan lokasi peternakan. Persatuan ini juga menerapkan sistem pengetahuan terapan, yaitu mempelajari sistem koperasi pesantren serta perbankan yang dijalankan oleh koperasi pesantren dan perbankan serta dikelola oleh para guru dan santri. Mengingat pesantren ini jauh dari kota dan di atas ketinggian 750 MDPL, pesantren pun kemudian mendirikan lembaga perbankan yang diharapkan menjadi cikal bakal berdirinya Bank Syariah.

\section{Sumber Daya Manusia}

Sumber Daya Manusia (SDM) mempunyai posisi sentral dalam mewujudkan kinerja pembangunan, yang menempatkan manusia dalam fungsinya sebagai resource pembangunan. Di dalam konteks ini harga dan nilai manusia ditentukan oleh relevansi konstruksinya pada proses produk. Kualitas manusia diprogramkan sedemikian agar dapat sesuai dengan tuntutan pembangunan atau tuntutan masyarakat.(Tjokrowinoto, 1995:28) Eksistensi bangsa Indonesia ditengah percaturan era global sekarang, akan dipengaruhi kemampuan sumber daya manusia Indonesia, terutama yang bercirikan kemampuan penguasaan ilmu pengetahuan dan teknologi dan pemantapan iman dan taqwa terhadap Tuhan Yang Maha Esa.(Ash-Shidiqie, 1996:9) Hal ini dapat diusahakan melalui pendidikan sebagai alternatifnya.

Pendidikan tidak bisa dipisahkan dari kenyataan hidup dimasa yang akan datang, yakni masa di mana anak didik itu mengarungi kehidupan. Oleh karena itu, pendidikan harus didesain untuk kehidupan lebih baik pada masa mendatang, begitu pula penanaman nilai-nilai yang mampu membekali kehidupan dimasa datang, yang bersumber dari agama juga harus diberikan. Ini meliputi kualitas dan keunggulan kompetisi sumber daya manusia, sampai dengan masyarakat yang ideal yang dicitacitakan sesuai dengan tuntutan masa depan yang berlandaskan nilai-nilai Islam.(Azizy, 2004:70)

Dalam perspektif Islam, pendidikan telah memainkan peran penting dalam upaya melahirkan manusia yang handal dan dapat menjawab tantangan zaman. Sumber daya manusia tersebut merupakan gerakan human investment adalah upaya pendidikan jangka panjang untuk melahirkan sumber daya manusia.(Yasmadi, 2002,25) 
Pendidikan Islam mempunyai peranan penting dalam peningkatan kualitas sumber daya manusia. Sesuai dengan cirinya sebagai pendidikan agama, secara ideal berfungsi dalam penyiapan SDM yang berkualitas tinggi, baik dalam penguasaan terhadap ilmu pengetahuan dan teknologi maupun hal karakter, sikap moral, dan penghayatan serta pengamalan ajaran agama. Secara singkat, pendidikan Islam yang ideal berfungsi membina dan menyiapkan anak didik yang berilmu, berteknologi, berketrampilan tinggi serta beriman beramal shaleh.

Pengembangan sumber daya manusia bukan merupakan persoalan yang mudah karena membutuhkan pemikiran langkah aksi yang sistematik, sistemik, dan serius. Karena berusaha memberikan konstruksi yang utuh tentang manusia dengan mengembangkan seluruh potensi dasar manusia. Dalam hal ini, pondok pesantren dengan segala potensi yang dimilikinya mempunyai peran serta terhadap pembangunan yang sedang berlangsung.

Untuk itu segala upaya yang mengacu pada pengembangan kualitas manusia sebagai sumber daya insani secara terus menerus dilakukan dengan indikasi peningkatan kualitas manusia Indonesia yang mampu berfikir strategis dan berwawasan masa depan adanya keseimbangan antara IMTAQ dan IPTEK.

Berdasarkan pemaparan di atas, secara jelas telah terdeskripsikan bahwa peningkatan kualitas sumber daya manusia pondok pesantren sebagai lembaga pendidikan Islam merupakan kebutuhan manusia yang akan senantiasa berkembang sesuai dengan perkembangan tuntutan zaman, karena manusia sebagai makhluk pedagogis dilahirkan dengan membawa potensi dapat dididik dan mendidik sehingga mampu menjadi khalifah di bumi serta penolong dan pemegang kebudayaan. Jadi, kualitas sumber daya manusia pondok pesantren sangat berperan penting sekali dalam menentukan kebahagiaan hidup di dunia dan akhirat.

\section{Metode Pembelajaran}

Sistem pendidikan di pondok pesantren sangat erat hubungannya dengan tipologi maupun ciri-ciri (karakteristik) pondok pesantren itu sendiri. Dalam melaksanakan proses pendidikan sebagian besar pondok pesantren di Indonesia pada umumnya menggunakan sistem pendidikan yang bersifat tradisional, namun ada juga pondok pesantren yang melakukan inovasi dalam mengembangkan sistem pendidikannya menjadi sebuah sistem pendidikan yang lebih modern. 
Sistem tradisional adalah sistem yang berangkat dari pola pengajaran yang sangat sederhana dalam mengkaji kitab-kitab agama yang ditulis para ulama zaman abad pertengahan, dan kitab-kitab itu disebut dengan istilah “Kitab kuning” Sementara metode-metode yang digunakan dalam sistem pendidikan tradisional terdiri atas: metode sorogan, metode wetonan atau bandongan, metode muhawaroh, metode mudzakaroh, dan metode majelis ta'lim.

Untuk menghadapi perkembangan metode yang diterapkan dalam lembaga pendidikan pada umumnya, berbagai metode pendidikan pesantren yang bersifat tradisional perlu disempurnakan. Perlu diadakan penelitian yang seksama terhadap efektifitas, efesiensi, dan relevansi metode-metode tersebut untuk menemukan kelemahan dan keunggulannya. Segi kelemahannya diperbaiki sedangkan segi keunggulannya dipertahankan. Dengan tetap mempertahankan ciri khas dan keaslian yang sudah ada seperti metode sorogan dan bandongan, pondok pesantren juga perlu mengadopsi sistem klasikal yang diselenggarakan dalam bentuk pendidikan non formal berupa madrasah diniyah. Dalam penyelenggaraan pendidikan mengunakan sistem klasikal (madrasi) ini adalah sebagai upaya untuk mempermudah pengajaran dengan menggunakan sistem bandongan dan sorogan.(sulaiman, 2010:4) Pondok pesantren yang melakukan pemaduan atau kombinasi berbagai metode (lama dan baru) dengan sistem klasikal dalam bentuk madrasah, tampaknya belakangan ini menjadi semacam mode. Akibatnya situasi dalam proses belajar mengajar menjadi bervariasi dan menyebabkan santri bertambah interest akibat aplikasi berbagai metode secara kombinatif. Maka pondok pesantren tidak lagi dipandang anti kemajuan dan sarang kebekuan, melainkan telah tumbuh dinamika metodik yang memberikan warna baru bagi kehidupannya.

Sebagai contoh, modernisasi yang dilakukan oleh Pondok Pesantren Modern Darussalam Gontor Ponorogo dalam bidang metodologi yaitu pondok modern Gontor dalam menggunakan metodenya adalah dengan menggunakan metode direct method atau metode langsung yang diarahkan kepada penguasaan bahasa secara aktif dengan cara memperbanyak latihan (drill) baik lisan maupun tulisan. Dengan demikian, tekanan banyak diarahkan pada pembinaan kemampuan anak untuk memfungsikan kalimat secara sempurna dan bukan pada gramatika tanpa mampu berbahasa dengan baik. Hal ini menunjukkan bahwa telah terjadi modernisasi di Pondok Modern Gontor dengan implementasi metode direct method. 


\section{Kelembagaan}

Dalam kesejarahan yang amat panjang, pesantren terus berhadapan dengan banyak rintangan, di antaranya pergulatan dengan modernisasi. Rahardjo, salah seorang pemikir muslim Indonesia, pernah 'menuduh' bahwa pesantren merupakan lembaga yang kuat dalam mempertahankan keterbelakangan dan ketertutupan. Dunia pesantren memperlihatkan dirinya bagaikan bangunan luas, yang tak pernah kunjung berubah. Ia menginginkan masyarakat luar berubah, tetapi dirinya tidak mau berubah. Oleh karena itu, ketika isu-isu modernisasi dan pembangunan yang dilancarkan oleh rezim negara jelas orientasinya adalah pesantren.(Rahadjo, 1995:1)

Dari perspektif kependidikan, pesantren merupakan satu-satunya lembaga kependidikan yang tahan terhadap gelombang modernisasi. Padahal, di berbagai kawasan Dunia Muslim, lembaga-lembaga pendidikan tradisional Islam seringkali lenyap, tergusur oleh ekspansi sistem pendidikan modern atau mengalami transformasi menjadi lembaga pendidikan umum; atau setidak-tidaknya menyesuaikan diri dan mengadopsi sedikit banyak isi dan metodologi pendidikan modern itu. Kenyataan ini dapat dilihat pada kelembagaan pendidikan tradisional di kawasan Timur Tengah yang tersimplifikasi atas tiga jenis: madrasah, kuttab, dan masjid. Hingga pertengahan akhir abad ke-19, ketiga lembaga pendidikan tradisional Islam ini relatif mampu bertahan. Akan tetapi, sejak perempatan terakhir abad ke-19, gelombang pembaharuan dan modernisasi yang semakin kencang telah menimbulkan perubahan-perubahan yang tidak bisa dimundurkan lagi dalam eksistensi lembaga-lembaga pendidikan Islam tradisional itu.

Pesantren merupakan dunia tradisonal Islam yang mampu mewarisi dan memelihara kesinambungan tradisi Islam yang dikembangkan ulama dari masa ke masa, tidak terbatas pada periode tertentu. Oleh karena itu, ketahanan lembaga pesantren agaknya secara implisit menunjukkan bahwa dunia Islam tradisi dalam segisegi tertentu masih tetap relevan di tengah deru modernisasi, meskipun bukan tanpa kompromi. Memang, pada awalnya, dunia pesantren terlihat 'rikuh' dan hati-hati dalam menerima modernisasi sehingga terdapat 'kesenjangan antara pesantren dengan dunia luar'. Akan tetapi, secara gradual pesantren melakukan akomodasi dan konsesi tertentu yang dipandangnya cukup tepat dalam menghadapi modernisasi dan perubahan secara luas. Akan tetapi, satu hal yang perlu diingat bahwa semua 
akomodasi dan konsesi itu dilakukan pesantren tanpa mengorbankan esensi dan hal-hal dasariah eksistensi pesantren.

Gelombang modernisasi sistem pendidikan di Indonesia pada awalnya tidak dikumandangkan oleh kalangan Muslim. Sistem pendidikan modern pertama kali yang pada gilirannya mempengaruhi sistem pendidikan Islam justru diperkenalkan oleh pemerintah kolonial Belanda, terutama dengan mendirikan volkschoolen, sekolah rakyat atau sekolah desa. Akan tetapi, sekolah desa ini pada awalnya cukup mengecewakan, lantaran tingkat putus sekolah yang sangat tinggi dan mutu pengajaran yang amat rendah. Namun di sisi lain, eksperimentasi Belanda dengan sekolah desa atau sekolah nagari, sejauh dalam kaitannya dengan sistem dan kelembagaan pendidikan Islam, merupakan transformasi sebagian surau di Minangkabau menjadi sekolah nagari model Belanda.

\section{Prasarana dan Sarana}

Pondok pesantren adalah lembaga pendidikan Islam tertua di Indonesia yang tumbuh dan berkembangnya diakui oleh masyarakat. Sebuah pondok pesantren memiliki lima elemen dasar yang terdiri dari: pondok, masjid, santri, pengajaran kitabkitab Islam klasik dan Kyai.

Pondok pesantren merupakan lembaga pendidikan yang lahir dari dana yang bersifat swadaya, atau hanya dibiayai oleh pendirinya saja. Dengan menyandarkan diri kepada Allah swt., para Kyai pondok pesantren memulai pendidikan pesantrennya dengan modal niat ikhlas dakwah untuk menegakkan kalimat-Nya, didukung dengan sarana dan prasarana sederhana dan terbatas. Inilah ciri pondok pesantren, tidak tergantung kepada sponsor dalam melaksanakan visi dan misinya.

Sejak dahulu di lingkungan pondok pesantren telah terkenal dengan pendidikan lingkungan hidupnya, yang bertujuan membekali para santrinya dengan berbagai keterampilan hidup (life skill) sebagai bekal hidup mandiri dan tidak tergantung pada orang lain setelah ia lepas dari pendidikan pondok pesantren. Oleh karena itu, untuk mendukung terlaksananya kegiatan ini, maka dari pihak pesantren harus menyediakan sarana dan prasarana yang menunjang, misalnya mesin jahit, alat-alat pertanian, alatalat pertukangan, dan lain sebagainya. Dengan keterbatasan atau bahkan tidak adanya sarana dan prasarana yang dibutuhkan tersebut maka akan membawa akibat sulitnya tercapai tujuan yang dikehendaki. 
Sebagai contoh, sebut saja pesantren-pesantren yang sudah masyhur di Indonesia yang telah memiliki prasarana dan sarana yang sangat memadai sehingga dapat dikatakan sebagai pesantren modern. Misalnya adalah Pesantren Raudhatul Hasanah di Medan, Pesantren Darul Arafah di Deli Serdang, Pesantren Gontor Ponorogo serta berbagai pesantren lain di Indonesia yang jauh sangat berkembang.

\section{Perubahan yang Dihasilkan}

Isu-isu pembaharuan pesantren sebenarnya telah diprakarsai oleh beberapa ulama muslim, diantaranya adalah K.H. Imam Zarkasyi, K.H. A. Wahid Hasyim dan K.H. Ahmad Dahlan. Di masa ini, masyarakat menaruh harapan yang sangat besar terhadap pesantren, seiring dengan visi dan misi pesantren untuk mendidik dan mengahsilkan insan kamil. Hanya saja, perjalanan pesantren dalam menjawab tantangan modernisme tidaklah mulus, banyak masalah yang sampai saat ini masih menjadi ganjalan untuk melangkah maju.

Permasalahan itu antara lain; pertama, pendanaan yang merupakan masalah paling serius di pesantren. Berbeda dengan sekolah umum atau perguruan tinggi, permasalahan pendanaan pesantren selain lokal-lokal balajar dan asrama, juga mencakup sarana konsumsi seperti dapur dan ruang makan menjadi agenda tambahan, lahan bermain, serta sarana olah raga, transportasi, sarana kesehatan,ruang inap tamu yang semuanya semakin memperluas medan kebutuhan pesantren sesuai dengan tuntutan zaman dan pola hidup yang berkembang dimasyarakat. Sedangkan pola swadaya pesantren dalam pembangunan biasanya menghidupkan kegiatan infaq dan shadaqah dari kalangan masyarakat, wali santri dan bahkan dari pengelola pesantren sendiri. Kedua, pencitraan di mata umat dan bangsa. Pencitraan tersebut biasanya dikaitkan dengan kebersihan dan penataan lingkungan. Pencitraan lainnya adalah karena kegiatan pengumpulan dan pembangunan dengan pola jaringan dan delegasi pengumpul derma keliling kekampung-kampung juga meninggalkan kesan pesantren dan santri selalu"mengemis". Dan ketiga, informasi dan publikasi yang agak tertinggal di pesantren. Ini merupakan bentuk umum permasalah pesantren di era modernisasi.

Menurut hemat penulis, dari beberapa penjelasan pada bagian sebelumnya, paling tidak perubahan yang dihasilkan sebagai akibat dari modernisasi yang terjadi di pesantren yaitu terkait pada bidang ilmu pendidikan misalnya perubahan pada tujuan, kurikulum, metode pembelajaran, pendidik, peserta didik, serta sistem evaluasi. Selain 
pada bidang tersebut, sistem kelembagaan, manajemen, pendanaan serta sumber daya manusia juga mengalami perubahan. Paling tidak, alumni pondok pesantren mampu berbicara banyak dan mampu memberikan sumbangan yang positif terhadap kemajuan bangsa dan negara kita.

\section{KESIMPULAN}

Modernisasi pendidikan pesantren dalam berbagai aspeknya memerlukan dukungan semua pihak, baik itu pihak internal pesantren, dan juga stakeholder, yaitu semua pihak yang terkait dan berkepentingan terhadap kemajuan pesantren sebagai lembaga pendidikan. Dukungan ini dapat dimulai dengan penghilangan stigma buruk terhadap pesantren yang dianggap sebagai lembaga pendidikan tradisional, pendidikan yang tertutup dan sulit berkembang. Dukungan lainnya bisa berupa pengadaan dana operasional, sarana dan prasarana pendidikan serta perlakuan terhadap pesantren dan sumber daya manusianya yang fair dalam melanjutkan pendidikan yang lebih tinggi dan dalam memasuki dunia kerja. Wa Allah a lam bi al-shawab.

\section{DAFTAR PUSTAKA}

Arifin, Imron, Kepemimpinan Kyai, Kasus: Pondok Pesantren Tebuireng (Malang: Kalimasahada Press, 1993).

Asari, Hasan, Esai-esai Sejarah, Pendidikan dan Kehidupan (Bandung: Citapustaka Media Perintis, 2009).

Ash-Shidiqie, Jimmly, (Ed.), Sumber Daya Manusia untuk Indonesia Masa Depan (Bandung: Mizan, 1996).

Azizy, A. Qodry, Melawan Globalisasi Reinterpretasi Ajaran Islam (Yogyakarta: Pustaka Pelajar, 2004).

Azra, Azyumardi, Pendidikan Islam Tradisi dan Modernisasi Menuju Millennium Baru, (Jakarta : Logos Wacana Ilmu, 1999).

Data Bidang Pendidikan Keagamaan dan Pondok Pesantren (PEKAPONTREN) Kementerian Agama RI.

Dhofier, Zamakhsyari, Tradisi Pesantren Studi tentang Pandangan Hidup Kyai (Jakarta: LP3ES, 1982).

Fatah, Rohadi Abdul, et.al., Rekonstruksi Pesantren Masa Depan (Jakarta: Listafariska Putra, 2005). 
Haedari, Amin, Masa Depan Pesantren dalam Tantangan Modernitas dan Tantangan Komplesitas Global (Jakarta: IRD Press, 2004).

Madjid, Nurcholis, Bilik-bilik Pesantren, Sebuah Potret Perjalanan (Jakarta: Paramadina, 1997).

Maghfurin, Ahmad, Pesantren Model Pendidikan Alternatif Masa Depan, dalam Ismail SM (Ed.) Dinamika Pesantren dan Madrasah (Yogyakarta: Pustaka Pelajar, 2002).

Mastuhu, Dinamika Sistem Pendidikan Pesantren (Jakarta: INIS, 1994).

Mastuki H.S., Pendidikan Pesantren antara Normativitas dan Objektivitas, Majalah Pesantren, LAKPESDAM NU. Edisi I/ Th. 1/ 2002.

Maunah, Binti, Tradisi Intelektual Santri Dalam Tantangan dan Hambatan Pendidikan Pesantren di Masa Depan (Yogyakarta: Teras, 2009).

Murtadlo, Ali, Gontor Masa Lampau dan KH. Imam Zarkasyi Sebagai Figur Pengajarnya, dalam KH. Imam Zarkasyi di Mata Umat (Ponorogo: Gontor Press, 1996).

Qomar, Mujamil, Pesantren Dari Transformasi Metodologi Menuju Demokratisasi Institusi (Jakarta: Erlangga, 2002).

Raharjo, M. Dawam, Pergulatan Dunia Pondok Pesantren Membangun Dari Bawah (Jakarta: LP3S, 1985).

, "Dunia Pesantren dalam Peta Pembaharuan” dalam M. Dawam

Rahardjo (ed.), Pesantren dan Pembaharuan (Jakarta: LP3ES, 1995), cet. ke-5.

Sulaiman, In'am, Masa Depan Pesantren (Malang: Madani, 2010).

Sulthon, M., dan Khusnuridlo, Moh., Manajemen Pondok Pesantren dalam Perspektif Global, (Yogyakarta: LaksBang PRESSindo, 2006).

Tjokrowinoto, Moeljanto, Pembangunan Dilema dan Tantangan (Yogyakarta: Pustaka Pelajar, 1995).

Yasmadi, Modernisasi Pesantren Kritik Nurcholish Madjid terhadap Pendidikan Islam Tradisional (Jakarta : Ciputat Press, 2002).

Yunus, Mahmud, Sejarah Pendidikan Islam di Indonesia (Jakarta: Hidakarya Agung, 1984). 